\title{
CORPORATE SOCIAL RESPONSIBILITY, HUMAN RESOURCE MANAGEMENT AND CORPORATE FAMILY RESPONSIBILITY. WHEN A COMPANY IS "THE BEST PLACE TO WORK": ELICA GROUP, THE HI-LIFE COMPANY
}

\author{
Mara Del Baldoa \\ a Assistant Professor, University of Urbino "Carlo Bo", Department of Economics, Society and Politics, Urbino, Via Saffi, 42, \\ Italy, mara.delbaldo@uniurb.it
}

\section{ARTICLE INFO}

JEL classification: M140, M1207

Keywords:

- corporate social responsibility

- corporate family responsibility

- employee

- ethical orientation

- family-work balance

- holistic development

- human resource management

\begin{abstract}
The purpose of the work is to examine the relationship between Corporate Social Responsibility policies, and Human Resource Management, particularly focusing on Corporate Family Responsibility. How do CSR practices impact on employees, their work, and their family life? How effective are these practices and how can they positively impact on the difficult "work-life balance"? With the aim to answer to these questions, the study combines the deductive and inductive approach. After presenting the theoretical framework, the second part of the paper analyzes the case of Elica Group, a large, multinational Italian family company that has been named one of the "best places to work" in the national and European contexts. The points of reflection that emerge from this study are centered on the factors that induce the company to adopt such policies, and the factors that impact their effectiveness. The results reveal that a robust ethical foundation on the parts of the company's founder and of its management, as well as their commitment to sharing values and objectives with the entire organization, are keys to Elica's success based on a holistic development (economic, social and environmental development).
\end{abstract}

Reference to this paper should be made as follows: Del Baldo M. 2013. Corporate social responsibility, human resource management and corporate family responsability. When a company is «The best place to work»: Elica group, the hi-fi company, Ekonomska istraživanja - Economic Research Special Issue 2013 


\section{INTRODUCTION}

Corporate social responsibility (CSR) can be defined as the extent to which firms integrate on a voluntary basis social and environmental concerns into their ongoing operations and interactions with stakeholders (EU, 2002; EC, 2011). During the last decades companies have been facing growing pressures to address social and environmental issues and to take into account the conformance to economic, social and ethical expectations from stakeholders.

Different theories attempt to explain CSR practices within a more systems-orientated view of the organization and society (stakeholder theory, legitimacy theory, and political economy theory) and many different ideas and concepts have been developed under the umbrella of CSR research, including corporate social performance (Carrol, 1979); corporate social responsiveness (Ackerman, 1973); corporate citizenship (Waddock, 2004); corporate governance (Jones, 1980; Freeman \& Evan, 1990); corporate accountability (Zadek et al., 1997; Gray et al., 1996); sustainability and triple bottom line (Elkington, 1994), holistic development (Sorci, 2007) and corporate social entrepreneurship (Austin et al., 2006). "Each of these diverse efforts share the common aim: the attempt to broaden the obligations of firms to include more than financial considerations" (Freeman et al., 2010: 235). Such a broad theme, in the past decade has attracted the attention of researchers from diverse disciplines, as well as policy makers and economic operators (Garriga \& Melé, 2004).

Different national and institutional environments impact on CSR whose domains include finance, principles of governance, formalization of the CSR policy, organizational structure of CSR, and dialogue with stakeholders (Young \& Marais, 2012).

Sustainable growth and larger and better employment are two challenges to confront for safeguarding the European model of society, which is based on equal opportunities, a high quality of life, social inclusion, social cohesion and a healthy environment. Enterprises - both large and globalized companies, as well as small and medium-sized companies - as the engine for economic growth, job creation and innovation, are considered key actors in delivering these objectives (EU Commission, 2006, 2010). Among the internal and external dimensions of CSR, two in particular address the firm's employees. Along with ensuring workers' safety and security of employment, emphasis is placed on human resources management policies, which have to be oriented towards: ensuring continual formation and instruction along the entire lifetime of employees; pursuing the best equilibrium between work, family, and free time; including employees in the company's management and benefits; informing them of the company's activities so as to stimulate their sense of belonging by fostering a shared set of values; enhancing personnel's responsibility; applying the principles of equality in salaries and in the perspective of career for women; attracting and retaining qualified workers; hiring the disabled, women, and people who are otherwise unemployed. The positive direct and indirect results of these practices are emphasized since they increase the effectiveness of human resource management (Hancock, 2005).

In the last decade, scholars started to developed these issues in the context of SMEs (small and medium-sized enterprises) and family business (Chrisman et al., 2003; Gallo, 2004; Deniz \& Cabrera, 2005). The empirical studies show that SMEs and family business tends to have a different, more personal relationship with employees and clients when compared with the non - family business (Wood, 1996). However, very few studies addressed the issue of Corporate Family Responsibility (CFR) conceiving the family as a stakeholder (IESE, 2008; ISFOL, 2009; AIDP, 2010; Fondazione Vigorelli, 2012; Strandberg, 2009).

Stemming from this premises, the present work intends to address aspects of a firm's 
CSR-orientation that touch on its relationship with its employees (the main internal stakeholders group), identifying the instruments and the areas in which they are applied that impact both work and life, and to identify the factors (related to a company's mission and governance) that render those instruments possible and efficacious. To this end, the motivations and values that induce the business's leaders to adopt CSR policies towards its employees will be identified.

The paper is divided in two main parts which methodologically follows the so called "abductive approach" which combines the deductive and inductive models of proposition development and theory construction. Its aim is to develop the concepts of CFR focusing on the issues of Human Resource Management -HRM, CSR employees and family CSR-oriented actions and to bridge the aforementioned gap in the literature and to contribute to open up a new line of research.

The first part (sections A) synthesizes the theoretical context in which the empirical analysis is found and develops the theme of CSR and HRM and CFR. The second part (section B) analyses the specific policies of CSR geared towards employees that has been successfully implemented by one large-scale Italian firm, Elica Group. This company has for years been distinguished for its best practices regarding work-family balance, which are the result of a value-based system and of a model of exemplary governance. Such "extreme case" helps develop reflections on the importance of embracing the cultural and anthropological roots of CSR. A discussion and concluding reflections follow (sections II).

\section{A. The theoretical framework}

\section{i. Corporate Social Responsibility, ethical orientation, and HR Management}

'CSR' expresses more than simply the requirement that business should be conducted ethically it refers to the notion of responsibility for the impact of corporate activity on the wider body of stakeholders, both internal and external stakeholders, and both economic (employees, customers, banks, suppliers, competitors) and social stakeholders (family members, the physical environment, the government, trade and business association, etc.) and it is this attribution of responsibility that underpins the willingness of society to legitimate business" (Gray et al., 1996).

CSR "enters" into the company's mission through the direct involvement of the owners/ managers, and is carried out through organizational processes and policies that are integrated with the corporate strategy, modifying corporate culture and corporate governance - in a way that favors processes of "democratic stakeholding" and of humanistic management (Zamagni, 1995; Argandoña, 1998) and the orientation towards the common good (Melé, 2002). This orientation could also consider the expectations of the family itself which is rarely considered by the companies' policies as a stakeholder.

The centrality of values, of relationships, of the human element, are not issues extraneous to for-profit companies and is particularly significant in small and medium-sized enterprises and family businesses (Spence et al., 2004; Del Baldo, 2012). An integrated CSR culture (which is the result of an authentic orientation towards multi-dimensional objectives - economic, social, ethical and environmental - the so called orientation towards the holistic development (Sorci, 2007; Elkington, 1994) is possible and effective where external-led policies and actions used to support reputation and stakeholder engagement are matched by internal business strategies and decisions driven by social and environmental principles.

The business' holistic development is founded on a system of universal ethical values that 
are often embedded in the local environment, which are actively practiced by the entrepreneurs, managers, and corporate stakeholders. Holistic development is by nature multi-dimensional, and can create shared value, contributing to the common good and to collective progress, starting with the local community of which these businesses are an integral part (Spence, 2000; Argandoña, 1998, 2008; Zamagni, 2007). Following this perspective, people - inspirers of the holistic development - and relationships lie at the center of the company's activities and strategies as well as the system of values shared among key actors, employees and other stakeholders (Sorci, 2007; Melé, 2002, 2012; Argandoña, 2003). The creation of lasting value for the corporate and environmental systems (the so-called "holistic success") is the fruit of a virtuous cycle that produce phenomena of accumulation of resources, mostly of an intangible nature, such as trust, cohesion, and credibility. Along with the willingness to respect and valorize people, productive correctness, and transparency, one of the values inherent in a coherent model of holistic development is a profound sense of responsibility towards the socio-economic and environmental context. "The welfare growth of a territory is, in fact, in large measure the result of the 'values' that the businesses, of every type, are able to create. These values are intended not only in the economic sense (capital, profits, salaries, taxes, etc.), but also in terms of competitive products, effective services, material wellbeing, moral satisfaction, security for the future, cultural growth and social development (....); created not only to benefit themselves, but also to benefit all (stakeholders, shareholders and citizens)" (Vergara, 2007: 57).

The afore mentioned principles affect employees, who represent a key stakeholder for the development of any CSR strategy or program. Among CSR systems several authors include training programs for employees, building of a socially responsible culture among employees, support of CSR internal entrepreneurship, involvement of the employees in the construction/evaluation of the CSR communication (reporting) and in the audit/control of the enterprise (Morgan et al., 2009). CSR initiatives and policies impact on the organizational context, shape employee perceptions, affect employee commitment and hence motivation (Collier \& Esteban, 2007) which are fundamental, particularly when companies operate globally in multicultural contexts (as in the case presented in the second part of the paper).

Notwithstanding the growth in the use of codes as a benchmark for employee behavior, frequently there appears to be a widening gap between a company's stated values (mission statements and codes of ethics) and principles and their relevance to organizational practice (Weaver et al., 1999). The effective delivery of corporate social and environmental responsibility initiatives depends on employee responsiveness which, in turns, depends on motivation and commitment that influence the employee's engagement pyramids (Melcrum, 2006; McElroy, 2001; Whitener, 2001).

The promotion of an 'ethical culture' - which encompasses both culture and climate - depends on how 'ethics' is embedded in the organization (Treviño et al., 1998; Clarke, 2004). "Salient behaviors - awareness of ethical issues, commitment to the organization, integrity, willingness to communicate openly about problems, to seek advice and reduced unethical conduct, improved decision-taking generate employee behaviors" (Collier \& Esteban, 2007: 26).

Further, best practice CSR firms' have programs and initiatives underway to support employees and their families learn about, and take action on, their social and environmental concerns at work, at home and in their communities (as in the following empirical case).

Bringing together several strands in the literature that bear on the question of the effectiveness of CSR policies, researches emphasize two levels at which effectiveness is determined: 
firstly, the range of organizational practices and procedures designed to create 'an ethical culture' across the organization; secondly, the enthusiasm with which employees espouse the organization's attempts to counter the effects of 'negative externalities' by ensuring that their activities create social, environmental and economic capital (Collier \& Esteban, 2007).

Moreover, successful CSR programs also depend on enlightened people management practices. Human Resource Management drive policy development and program implementation in HR areas (i.e. recruitment, training, communication) that directly support CSR values (Buckley et al., 2001; Weaver, 2004). HR function contribute to the establishment of effective CSR policies by delivering on the responsibilities that companies have to their employees as stakeholders (Mees \& Bonham, 2004). Wellness, diversity management, work-life balance and flextime policies are CSR programs directly within the HR manager's purview. Wellness programs can become a platform for engaging employees in discussions about "personal sustainability" and provide support for employees in the areas of stress management, spirituality at work, healthy lifestyles, etc. Employee volunteering programs can help build out the employee value proposition and employer brand while concurrently delivering on the firm's CSR goals for community engagement and investment, as well the development of an unpaid leave program for employees aimed to pursue personal projects aligned with company values. All these programs require management support, rolemodeling and ongoing communications - which, if in place become further vehicles to fostering employee awareness of, and engagement in, the firm's CSR approach (CBSR, 2003; CIPD, 2002; Grant, 2008; Koos, 2012). Personnel policies and practices is a way to bring ethical values into everyday routine (Melé, 2009).

Finally, leadership has a crucial role in shaping ethical organizational culture through leaders' moral behavior, corporate mission, vision and values, evaluation processes and monitoring, ethical training programs, applying ethical values to decision making and in intra-organization procedures and structures. Ethical leadership requires personal attributes (honesty, ability to listen allowing others autonomy of choice, openness, willingness to consult and to learn) and manifests itself in a series of executive behaviors (i.e. gaining a real understanding of the culture; building ethics and values into 'hearts and minds' by means of ethics training programs; building ethical achievement into performance evaluation, creating channels of communication between the company and stakeholder groups) (Treviño \& Brown, 2004). A fundamental element for the effectiveness of ethical commitments and the development of internal and external trust lies in a strong 'steer' from the top (Collier \& Esteban, 2007).

\section{ii. CSR and Corporate Family Responsibility}

The theme of CFR is not particularly developed in the managerial, entrepreneurial and economic literature and has emerged only recently after the affirmation of CSR theories. This topic crosses diverse disciplines and diverse points of view (economic, sociological, ethical, organizational, legislation, and anthropological) and is significant on both the theoretical and practical levels, because the need to balance work and family must be responded to with concrete instruments and policies aimed at improving the relationship between quality and satisfaction in both work and life.

More generally, there exists a gap that only recently economic researchers have begun to address - the consideration of people not only as economic operators but in their integrity, that is, as immersed in the rich fabric of interpersonal relations, and the consideration that such relations are the fundamental object of analysis for understanding the logics of operating and developing a business (Faldetta, 2008). Considering the family as a stakeholder of the firm means stressing the advantages that come to the firm from employees' assets inserted in cohesive social contexts, to 
the highest level of solidarity and social control, and can guarantee a stable social fabric that is economically and culturally rich (Hochschild, 1997).

From the theoretical point of view, different models describe and interpret the relationships between work and family (Zedeck \& Mosier, 1990).

According to the spillover theory, there exists a type of correlation of cause and effect between work and family: that which a person lives in his work is reversed in his private life.

Compensation theory argues that people search in one of two places (work or life), and that which they cannot find in one they find in the other; segmentation theory considers the two environments as separate and without reciprocal influences: the family is the site of affects and relationships; work is the site of payments and capital. Nevertheless, according to the instrumental theory, one environment should be the instrument for obtaining results in the other. Finally, conflict theory argues that the search for satisfaction in one of the two environments can only be achieved by sacrificing the other.

In searching for a perspective that can reconcile work with private life and familial responsibility, that is, work with responsibility towards one's family (Werbel \& Walter, 2002), the diffusion of CSR policies and practices therefore becomes important for effective work-family balance policies. The demand for such policies - which can be classified in diverse ways (Ponzellini \& Tempia, 2003) is rising, especially for flexible hours, part-time work, understanding and trust (towards colleagues), flexibility in emergencies and paid or unpaid leaves of absences (Kodz et al., 2002; Yeandle et al., 2002).

The need for balance, which is associated with a higher quality of life (Greenhaus, 2003), is rendered even more acute in recent years, which have been associated with an increase in female employment and address such factors as the family's life cycle (Waismel-Manor et al., 2002) and the job's characteristics which require an equilibrium between work and family responsibilities. At the same time, businesses have become more understanding in recognizing that the effective implementation of such practices requires a change in culture, values, and behaviors (Bond et al., 2002).

However, there are still many obstacles which are linked to the fear of carrying out these policies on the perspective of career and payoffs, to the dominant culture in the different work environment and to the lack of support from the management. And on the concept of the efficacy of these policies there is no connection between points of view of employees and employers due to a trade-off between what is requested and needed by employees, and a company's diffuse cultural orientation (Desrochers et al., 2004).

Few quantitative studies are focused on the correlation between the needs for these policies and the improvement of firm performance (Greenblatt, 2002; Glass \& Finley, 2002). More often the focus is on equal opportunity policies more so than those of responsibility towards the family. In particular, the results of some studies reveal that, on the one hand, there seems to be a link between formal instruments, such as the availability of benefits to support family needs, with informal organizational factors, such as the organizational culture, the support of the management and the amount of autonomy that employees enjoy (Allen, 2001; Anderson et al., 2002; Behson, 2002, 2005).On the other hand, indexes measuring the personnel's morale, commitment, production, absenteeism, and turnaround, demonstrate that there exist economic benefits that derive from the implementation of work-family balance instruments. Among the benefits one can enumerate (Bevan et al., 1999): the increase in: assistance for illness (Rode et al., 2002); in employees' pay and productivity; in the length of employment (loyalty); and in the effectiveness of 
personnel selection and hiring procedures.

The application of such initiatives implies several important benefits at an organizational level (AIDP, 2010): minor resistance to change on the part of human resources; creativity and individual contribution to the process of innovation; - attractiveness (in terms of employer branding) and reduction of turnover; reduction of costs and increase in the productivity of employees thanks to the promotion of a culture of performance; reduction of reintegration time after a long absence (such as maternity leave). Effective policies concerning the work-family balance are linked to higher quality and satisfaction of people both in their work and in their private life (Kapitàny et al., 2005).

Other studies that have gathered information on the employers reveal that family policies have significant effects on their needs (Dex et al., 2001), though not always positive and therefore of limited success. The studies centered on economic performance only examine the results of work-family balance initiatives and not the policies themselves (Gray, 2001). The relationship between economic performance and work-family balance policies is certainly not clear, nor easily analyzable; nor can the opportunity to implement such policies able to be determined only by economic reasoning (Butler et al., 2004). The usefulness and advantages can be evaluated only in the long term and are therefore difficult to measure only from the economic-financial point of view.

The case is different for companies that wish to assume the responsibility of providing for the well-being of its employees based on ethical motivations, and thus do not consider these policies merely as investments to evaluate only through cost/benefit analysis. This helps affirm that such policies posit a supportive corporate culture, one that can understand and meet the needs and expectations of its carriers of interests and can recognize the centrality of the human element. Such a corporate culture finds fertile ground in companies that propose social responsibility at the center of their strategic design and which consider human capital, trust, and reciprocal loyalty (Roehling et al., 2001) as drivers of social and economic value. In other words, it founds its framework in the orientation towards the holistic development, a concept discussed in the following section.

Researches on the conflict between work and family in different industrialized countries are limited, and there are few comparative studies developed with respect to the specific political, normative, economic, social, and cultural contexts that characterizes each country (Hofstede, 1980). The available data reveal similar situations among different countries (including the EU, U.K. and United States) and highlight the need for greater flexibility in the workplace, especially regarding women (Reynolds, 2004).

The policies adopted by various states are diverse: the United States favors research and development of instruments on the market; in Japan policies for the family has registered a notable development in recent years. In France, paid maternity leave was legislated as early as 1913 (Fagan, 2003; OECD, 2002-2005; Todd, 2004). In Australia, satisfaction regarding the work-family balance decreases at the same rate as the amount of hours per work increases.

In 2008 IFREI research (International Family Responsible Employer Index) held by IESE Business School (Spain), introduced a new on-line system which allows public or private companies to make an assessment as to what favors a balance between work and family (AIDP, 2010; EURISKO, 2009; EU, 2010). A model was proposed which defined four levels of organization regarding the corporate and social model: "Systematically enriching corporations" are those characterized by a responsible family culture: "Discretionally enriching corporations" are those in which some bal- 
ance policies and practices are present; "Discretionally polluting" companies are those in which some policies exist but are rarely applied; finally "Systematically polluting" companies are those in which responsible family policies are absent.

In 2009 the Italian Ministry of Equal Opportunity began adjustments to the IFREI in Italy, including specific Italian cultural realities. The research, which involved 216 businesses (SMEs and large enterprises) highlighted how most of these companies fall into the "discretionally polluting" category and only $2 \%$ fall within the category of top "systematically enriching" companies. In 2010 data confirmed the delay compared to other countries: the European average of enriching companies is 39\%, in America 34\%, Asia 55\% and in Africa 62\%.

There are other cases of CFR practices in Italy at a regional and local level (Tuscany, Veneto and Piemonte) which have been developed under the General Directorate for Social Welfare and Family Policies. The early involvement has started with the Green Paper on reconciliation of family and work life, issued by the regional government on November 2010. One such example is the Region of Lombardy, which has placed the issue of reconciliation between family and work at the centre of its policy agenda. Lombardy Region (2011) formulates the White Paper as a Roadmap for reconciliation of family and work life. Change is to be promoted at both the cultural and organizational levels by focusing efforts in two main directions: considering the "reconciliation value chain" in its entirety: family mainstreaming and multi-level governance; and further the interconnection of people, ideas and resources: networks and pluralistic governance, implemented in all 12 Provinces of Lombardy.

\section{B. The case of Elica: a family friendly company}

\section{i. Methodology}

The following empirical study is qualitative in nature and has been undertaken through the case study method (Yin, 2003). The development of a case study represents a "strategy of research that is concentrated on the comprehension of the dynamics that characterize specific contexts" (Eisenhardt, 1989: 532). Qualitative research utilizes the "theoretical sampling" model, privileging the relevance of the case rather than its representativeness (Flick, 2009). Recently scholars have called for a return to in-depth methods (Gartner, 2007; Naumes \& Naumes, 2006) considering them important on the scientific level to generate theoretical propositions (Eisenhardt \& Graebner, 2007) - that can be tested through quantitative research. The case-study methods and qualitative approaches are largely concerned with the context of studies on CSR, to meet both intellectual goals as well as normative ones - that is, to suggest possible actions that give voice, even though the narrative approach (Bebbington et al., 2009), to successful experiences.

The Elica Group was selected for three main reasons. First and foremost, it is among the toprated companies in Italy and Europe for its CSR practices and for the attention given to its workplace environment, and has received numerous awards to this effect.

Second, it is part of a field of over 200 businesses in the Marches region that have been rated "excellent" in terms of quantitative and qualitative performance (monitored for over 30 years). It took 5 th place among the 10 best Marchegian firms. Elica is, furthermore, one of only a few largescale Italian firms. In 2005 only 3,215 large-sized firms were present in the Italian economy, i.e. 0.1\% of all firms (Calcagnini \& Favaretto, 2011).

Third, Elica falls within a sample of Marchegian businesses that have been previously examined in an explorative study, selected for their explicit orientation towards sustainability and CSR that 
combines high levels of social and intangible capital linked to specific qualities of the region's culture in which it is a part (Del Baldo, 2010). The Marches region is famous for its diffuse entrepreneurial and rural fabric and for the presence of relevant industrial district. Celebrated in the work of Fuà and Zacchia (1983) and known as "Third Italy", it is characterized for a high degree of socioeconomic and environmental development and for the present of a remarkable level of preserved social cohesion (Putnam, 1993). Different national study that analyzed the geography of sustainability in Italian provinces in economic, social, and environmental terms, found the Marches in the top level, with points of excellence for social cohesion and with superior value on all three fronts (Unioncamere, 2003, 2007, 2010).

The research - which was conducted between May 2011 and May 2012 - is based on the triangulation of sources (semi-structured questionnaires, direct interviews, documentary analysis, focus groups, participant observation) and was carried out in two phases. In the first phase, a questionnaire was mailed out to the highest levels of the firm (Chairman), members of the Board of Directors (Chief Executive Officer, Executive Director, Independent Director) and those responsible for key functions (Chief Financial Officer; Sales Director; Chief of Human Resources; Investor Relations Manager), in addition to four employees ( 2 office workers and 2 factory workers). This was followed by interviews (which lasted on average an hour; recorded, transcribed and evaluated) with a total of 12 people during 6 site visits.

Participant observation was chosen as research strategy (Corbetta, 2003) which allowed to enter in a direct manner and for a relatively long period in the company and to establish personal relationships and interactions with its members, rendering possible to understand through a process of identification, their motives, goals, values, and behaviors.

For over a year, in fact, it was possible to attend different meetings, open days and other events (i.e. workshops and conventions) addressed to Elica's employees, alongside the Chief of Human Resources and his collaborators during the course of their activities, and to observe the physical context, social context, the formal and informal interactions.

Furthermore the focus groups technique (Barbour, 2007; Puchta \& Potter, 2004; Morgan, 1988; Merton, 1987), used in combination with other methods (semi-structured questionnaires, direct interviews, documentary analysis and direct observation), has been useful for generating hypotheses based on informants' insights, and getting participants' interpretations of results. The groups were formed by 'Elica people' with different positions and roles (i.e. CEO, Executive Director, employees and other stakeholders such as students and clients). Different group discussions were carried out during moments of pause in the company cafeteria and meeting areas and were aimed to produce informality in the discussion, create a liberal climate - in the same way in which opinions are produces, expressed and exchanged in everyday life - in order to avoid studying attitudes, opinions and practices of human beings in artificial isolation from the contexts in which they occur (Patton, 2002) and to stimulate the respondents beyond the answers to the single interviews (see Flick, 2009: 196).

These forms of primary source information were then combined with secondary data elicited from an analysis of the company's website (online material taken from the firm's website, which provided extremely rich documentation on its Group profile, brands, investor relations and press reports) and several types of documents: annual reports, ethical code, statute, internal dealing code, documents on social organs, shareholding and equity and shareholders meeting rules, corporate governance reports, corporate governance and ownership structure report, financial data (budget and reports, key-rations, analysts coverage), presentations (results conferences, Star 
Conference Milan, London Star Conference presentations, quarterly statements), press kits, videography. Finally, other internal documentation, such as reports and publications, were acquired during company visits.

\title{
ii. Data
}

Brief Overview and Company Profile

The Elica Group is a multi-national group that originated as a family business. It was founded in 1970 by Ermanno Casoli at Fabriano (its headquarters), a city in the North-East of Italy. Listed on the Star segment of the MTA Italian Stock Exchange since 2006, Elica is today the global leader in terms of units sold (17\%) and European leader in the design, manufacture and sale of motors for home appliances and central heating boilers (41\%). By 1978, Elica had 130 employees and revenues of 3.5 billion euros. From the end of the 1990's, the Elica Group began a developmental phase consolidating its position as a global player. Its Latest (2011) Financial Highlights show: Consolidated Revenues of 378.4 million euros; Group Net Profit of 4,1 million euros; EBITDA of $26.5 \%$ and EBIT $12 \%$.

After the premature passing of Ermanno Casoli, his son (Francesco Casoli) joined the Group, actually chaired by the same and led by a Chief Executive Officer. The Group's ownership structure is characterized as majority family-owned.

With 2,966 employees - 1.720 men and 1.246 women (year 2011) - , of which 1.512 are abroad and 1.454 in Italy, the group is organized around two principal Business Units: the Range Hood Business Unit and the Motors Business Unit and different brands. The Elica Group has 9 plants - of these, 4 are in Italy. The structure of the Group, of which Elica S.p.a. (Italy) is the leader, comprises different controlled companies and associated in India, Japan, China, Poland, Germany, Mexico, Russia Federation.

The following values (Tab. 1) represent the strong reference points for all the activities, together with the commandments (Tab. 2) of the founder and of the current Chairman.

\section{TABLE 1 - ELICA GROUP'S VALUES}

\author{
Love your customers - put passion into working for them \\ Use innovative thinking \\ Make it easy for everyone to be involved in their own work \\ Employ and communicate total energy \\ Identify new objectives and achieve them \\ Stay curious and never stop learning \\ See change as an opportunity \\ Fight to reduce costs and simplify your work
}

Source: Company's web site 
TABLE 2 - THE INSPIRING PRINCIPLES FOR ELICA GROUP'S WORK

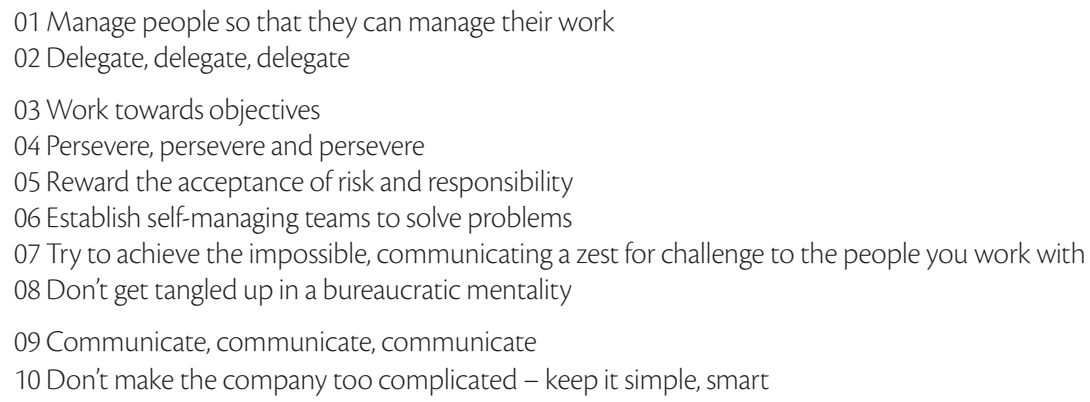

Source: Company's web site

CSR practices and Projects: the Focus on Human Resources

The Elica Group has always placed a strong focus on its employees. The HRM policies ensure employee performance through combining the qualities of the individual with the Group culture and values. Elica's CSR orientation and its particular attention to human resources is solidified by a plurality of instrument; those that place the work-family balance at the center are presented below in the following sections.

The Group's CRS activities aims to improve skills, the well-being of employees and their families, of the local community, and to safeguard the outside environment. They are divided between internally and externally addressed initiatives. The first category includes: Elica Life (a collection of tools and actions aimed at reaching the well-being of employees and their families within and outside the working environment) and internal communication activities (aimed to promote internal knowledge of the company reputation; to contribute to the knowledge of employees concerning corporate strategies; and to strengthen through direct relationships the sense of belonging and responsibility in relation to the work carried out and the results achieved). The second category includes: certifications, environment and safety, World Class Manufacturing: industrial relations and the numerous social initiatives.

Within the externally addressed initiatives, the system of industrial relations - based on a participatory system - represents a model of Elica's corporate excellence. Trade union organizations are the principle interlocutor with whom Elica can follow a process of raising the well-being of all of its employees. One result from this way of operating is the agreement Elica's 2010 "plan for occupational sustainability". This type of accord, which is extremely innovative, has called for investments and educational opportunities in a territory experiencing the effects the international crisis, where the majority of businesses are talking about closing factories and restructuring; it now has been adopted by other local businesses.

Elica's best practices in industrial relations have even been exported to Poland; it is the only Italian company to have signed an agreement with the largest Polish trade union, Solidarność. The model of industrial relations (adopted since 2009) is synthesized into 8 points: participatory method; system of communications; industrial relations; organization of work and employment (i.e. Commission for training and Commission for equal opportunity, and integration of foreign workers; quality; environment and security - green products, recycling systems, ergonomics, solutions); Elica Company Welfare and Corporate Family Responsibility; Rewards System Award (for 
results linked to the profits of the Group - EBIT indicator-and reaching the objectives of individual attendance; monthly production bonus and bonus for old aged employees).

Among the internally addressed initiatives, Elica Life - created in 2006 - represents the syntheses of Elica's human resource and corporate family-oriented policies. Elica's work-life balance policies are renewed yearly, adding on or improving the initiatives aimed to promote the quality of life of its workers. The principle initiatives of CFR are summarized below (Tab. 3).

\section{TABLE 3 - THE ELICA LIFE INITIATIVES}

The "Member Card" and the Member Card Postepay 2011

Elica for Kids

"I AM" and "I AM POLAND"

Work Life Balance agreement and Sustainability Plan

Elica Fitness and Wellness

Gift Certificates and Oil

E-Straordinario
The Card is utilizable by all of the employee's family and grants access to a series of subsidized services and discounts within the commerce, services and healthcare area. In 2011 it became also a "Postepay" (credit) card.

Elica provides funding towards purchasing scholastic books for all employees' children. It therefore favors the dissemination of culture, but particularly supports employees in the educational management of their children.

Elica began the internationalization program "Elica I AM" in 2007 (and in 2011 in the subsidiary Elica Group Polska), a study abroad program and English language courses for its employees' children to improve their language skills, to develop their capacity to engage with different places and cultures and to communicate to family members a open and multicultural ideas.

The company has transformed its contracts from full-time to part-time upon the request of employees, granting the possibility for its many female workers to better balance their working activities and their personal life.

Different are the grants: unpaid family leaves for foreign employees who must return to their country of origin; paternal leaves to all new fathers after the child's birth; maternity leaves and child care are given to all new mothers at the end of the optional post-partum leave; further unpaid leave within the first year of the baby and the possibility to choose a daily start time; monetary bonus for all employees on the birth of their first child; wedding bonuses; 6-month unpaid leave of absence for treatment for dependents affected by alcoholism or drug addition; advance payment of the retirement allowance.

Aerò, the Elica gym, was established in 2010 to promote the philosophy of wellbeing and quality of life. "The fitness project was created as a response to the needs and requests expressed by our dependents (managers, professionals, administrators, workers, men and women" (Elica CEO).

"During Christmas we help our employees in their shopping by providing gift certificates that are honored in local supermarkets, as well as 5 liters of Olive Oil". (Chief of Human Resources).

The project - in collaboration with the Ermanno Casoli Foundation - seeks to bring together two worlds of the arts and business. The educational activities represent an important occasion for the construction of a group identity, founded on sharing socio-cultural experiences and values.

Source: Author's elaboration

Finally, we mention the attention paid to the Group to human resource education and training. Different are the programs and the tools implemented, such as language and information systems educations, training courses, "tool courses" for new employees, project and team working, etc. 
In Mexico, Elica has been awarded by the Instituto Nacional para la Educaciòn de los adultos for its work in improving the scholastic education of those who work with ElicaMex. In addition, a formative system for the top management has been put in place. For a number of years the Group has collaborated with top business schools (i.e Bocconi University) for recruiting, employer branding and education.

For the fourth consecutive year, Elica was included in the Top Employers Italy and awarded in 2012, the best Italian companies to work for. The CRF Institute (an independent international organization which from 1991 evaluates and certifies over 2,500 companies in 12 countries and on 3 continents) recognized Elica as "a company excelling in the management of human resources" (CRF, 2012). The survey, carried out according to strict standards established by the Top Employers HR Best Practices, extensively evaluated the HRM system of Elica S.p.A. A subsidiary of the Elica Group (Polland), was also awarded the prestigious Top Employers PolPolska 2011 certificate. The "excellent" rating was given for its payroll policies, work conditions and benefits, corporate culture, education and development, and career opportunities. The certification reveals Elica's points of excellence: corporate value coupled with social commitments; corporate welfare and work-life balance; transparency, opportunities to grow, career advancement, the valorization of diversity, innovation and creativity, and organizational well-being.

Elica is therefore fully a part of the prestigious club of 32 top Italian firms, serving as a significant and meritorious example in the entrepreneurial panorama for having demonstrated great skill in valorizing its human and intellectual capital, thanks to effective strategies and management policies by its human resources department.

"We are very proud of these awards, which recognize the bounty and continuity of the work that we're doing. The first objective of human resources management is to give support to the company in order to create for its people the best conditions for personal and professional development and provide the necessary tools for them to become the main actors in their own growth with the same willingness dedicated to the group's growth" (E. Zampetti, HR Manager, 12 June, 2011).

Elica has also been recognized as among the best large companies to work for in Italy and was awarded by the Great Place to Work Institute, which evaluates the quality of work environments of over 1,000 businesses throughout Europe. In 2001 the company was awarded first place in the "Inspiring special category", which concerns all activities undertaken to create employees' involvement and awareness around the significance of their work in reaching the organization's results and for the wellbeing of the company.

"To have reached the absolute first place in Italy and the first in Europe in such a few years shows the work we're doing in the area of human resources. This award is a testament to our concern with education, skill development, and our attention to the well-being of our people." (M. Scippa, Chief of Human Resources, 27 May, 2012).

\section{iii. Discussion}

From an analysis of this rich set of data, one finds Elica's approach to CSR integrated, shared, effective, since it addresses all aspects of corporate activity, both the strategic as well as the operational levels.

In particular, the company's tension towards the holistic development involves all dimen- 
sions: ethical, economic, social and environmental. The root of this "force" must be identified in the value recognized primarily in the individual, in his/her totality and in his/her diverse dimensions of professional and family life. Among the HRM policies and CSR actions, the policies of CFR touch on all of the different ways of reconciling work and life and they are effective because they are the result of a great capacity to listen, and of a "passion" for people that characterizes the Group. It is this strong anthropological framework that constitutes the primary strength of the company, starting with the values that the founder and the upper-level management have been (and are) capable of transmitting and of reinforcing, through relations with, and management of, diversity (ethnic, cultural, professional), which is considered an asset. All of this finds official recognition in the awards given to the Group for being "a best place to work".

Consequently, a first area of reflection relates to the values system of the family business model which includes an attachment to the territory, to local institutions, and to dependents. Elica Group demonstrates the strength and validity of a familial matrix. The family is therefore not a constraint or a source of conflict, but the primary source of intangible resources. In the same way, the territory of origin is not a limit or boundary, but the source of legitimization, of cohesion, of social capital, from which it derives energy and resources.

A second area of reflection regards the importance of the presence of charismatic leaders, capable of nurturing and presiding over changes in value. In the Group, the managerial and entrepreneurial team possesses not only leadership capabilities, but also charisma, and is able to develop talents and virtues among its collaborators. The interpretive key of a family business is found in its 'cultural models' (Dyer Jr., 1986). The leader presides over changes in values (Schein, 1983) and plans the "organizational culture" . The leader's values that the founder of Elica has injected into the business are a strong work ethic, and the importance given to individuals, to human resources and to their families. These values have been part of the Marchegian cultural heritage and traditional of the religious and rural culture. The current Chairman has known how to reinterpret these in a dynamic way through managing the diversity of the Group's stakeholders and employees.

A third area for reflection regards Elica's capacity to stimulate and contribute to the progress of individuals and the socio-economic contexts in which the Group is present. The rootedness in its territory of origin is a jumping off point for confronting the world armed with a collection of authentic values, which guide the business in its acts of decision-making. Precisely because these values have an anthropological foundation, they are "universal" and find points of contact in diverse cultures and in the relationship with diverse geographic areas. The will to "infect others" and "to be infected", help marry local and global, and to reinforce cohesion and a sense of belonging to diverse territories.

Lastly, a distinctive attribute of Elica Group is its capacity to listen, to communicate, and to create relationships. Elica enjoys an authentic rapport with its stakeholders centered on reciprocity: that is, a capacity to converge, or to go in the same direction and to enter into harmony. Goals, expectations, visions, values are constantly reinforced through diverse channels of communication (direct relations, organizational practices, processes of governance (transparency, sharing, democracy), inside and outside the firm, and through a plurality of forms of stakeholders dialogue and engagement. Its cohesive organizational climate and its flexible organizational structure make possible a decision-making process, which is based on trust, collaboration, participation and sharing. 
To point out these reflections, some quotes derived from the interviews to the managers are cited:

"Considering our employees in their totality safeguards their life inside and outside of the firm. It's for this reason that we work towards a perspective that is both organizational and individual. The business is involved in favoring the development of instruments and actions linked to reaching employees' well-being, both in work and outside of work." Chief of Human Resources, 11th March, 2012 ).

"Excellence cannot be created if we do not live in a workplace which practices excellence in the care of the individual, both within and outside the workplace environment." (Elica CEO, 10 September 2011).

"For us, human capital is a competitive edge of the highest quality. Elica is for us an engine through which passion, experience, innovation, well-being and listening to internal and external needs can create an impression on our surrounding environment" (F. Casoli, President of Elica Group, 27 May 2011).

"The policies of work-family balance are considered expressions of our values and business culture" (HR Specialist, 11th March, 2012).

"In Elica there is the conviction that the bases for healthy economic growth are in the diffusion of cultural values, which are first of all ethical and present in a good quality of life at all levels. "Culture spreads through contamination" is a recurring concept used by our President" (Independent Director, 11th March, 2012 ).

Furthermore answers to some of the key questions asked to employees are reported and these highlight their perception on the company's policies of work-family balance.

"What do you think about the programs that your company offer its dependents to help reconcile their working life with that of their private or family life?" "Among the most significant initiatives which meet my expectations and which I appreciate the most as a concrete sign of the esteem the company has for its personnel, are the changes in production working hours at the beginning of the school year; the chance to telework from home; the sharing of the same job by two workers and the planning of working hours with colleagues, particularly requested by women like me who have just had a baby. In general I appreciate the possibility of working part-time and the maximum amount of flexibility on the rules regarding leave for the care of children and family members. The company provides for periods longer than required and unpaid leaves when a particular familial problem emerges. Elica is one of the few companies to apply these opportunities" (Female employee, 11th May, 2011).

In Elica, the strategic approach to holistic development is reflected both in its mission as well as in its government. The activities of stakeholder dialogue and engagement are numerous and systematic and present elements of excellence with specific reference to its employees, in terms of which the Group has developed an extremely rich network of initiatives and programs, aimed at raising the value of human and professional growth.

Elica is a collaborative enterprises (Tencati \& Zsolnai, 2008) whose model of industrial relations is a clear example of how workers represent the primary value of a corporate organization and is a concrete example of democratic stakeholding. Elica is also an example of a pathway to sustainable development centered on soft and intangible elements (social, intellectual, and relational capital).

In Elica the authentic adhesion to the philosophy of CSR signals the passage to a manage- 
ment model that considers all stakeholders and opens the field to a more ethical form of governance founded on trust, relationships, transparency and communication, which elicit the hypothesis that a robust ethical and value-based perspective of the entrepreneur and his management team (that is diffuse within the organization) guides the company towards the adoption of CSR practices which favor holistic growth, reducing conflicts, reinforcing social cohesion and corporate culture, and which translate into reciprocal benefits for the firm and the community inside and outside.

With specific reference to work-family balance policies which are represented by the presence of a tendency towards the CFR, the Elica model falls into the "systematically enriching" companies category (IESE, 2008; AIDP, 2010).

In Elica, CSR is not perceived as an added cost but as an investment and a resource. CSR is part of this company's DNA. This orientation is not decoupled' from or opposite to, but is however integrated into, every day practices and procedures (Weaver et al., 1999). This is an approach to CSR that expresses a socio-competitive synthesis. The correlation between corporate performance and social commitment is driven by Group's values and capacity to "card" relationships. The philosophy and practices of CSR help improve its performance in that they firstly raise the value of intangible resources - that is, the organizational capital, human capital and relational capital - which are the true core of the company's success.

\section{CONCLUSION, LIMITATIONS AND FURTHER RESEARCH}

This work has attempted to contributes to the practical point of view of promoting an understanding of best tools for implementing CFR practices, as well as provides reasons for their effectiveness.

From the scientific point of view, the work has developed reflections aimed to advance the comprehension of the relation between the themes of CSR and the reconciliation of professional and familial responsibilities, opening lines of inquiry that are currently underdeveloped on the issue of work-life balance and of CFR. On the one hand, the paper identifies the factors that are at the base of a successful CSR model that contributes to the valorization of employees. On the other hand, the empirical analysis underscores the importance of policies reconciling work and life, which are centered on respect for, and the valorization of, the individual. These policies are positively linked to the firm's intangible assets (reputation, productivity, loyalty and legitimacy) and suggest concrete pathways which other companies can adopt to introduce instruments through which synergies in relationships between employees and the firm can be created.

Through the use of various research strategies and techniques of data collection (and, in particular, by means of interviews, focus groups and participant observation), it was possible to verify how the information contained in the Elica Annual Report, in the newsletters and other documents, in different reports carried out by the organizations that have awarded the Group (i.e CRF Institute), as well as information inserted in the Group website, and communicated through other media - relating to human resources and CFR policies - were effective and authentic.

The empirical analysis helps formulate the following proposition: "effective tools and actions of CSR sustainability particularly address to employees can be developed on solid ground if they find their own roots in cohesion around shared values and objectives, nurturing processes of multidimensional development which place at their core the "person" and its needs and attitudes". This proposition can be tested in a further phase of the study, using broad-based qualitative and quantitative research designs aimed at analyzing other companies, both of larger and 
smaller size, belonging to the same country (Italy) or to different ones.

The purpose of the exemplary case-study was to provide empirical evidences to be integrated with the proposed theoretical framework. Nevertheless, the work intended to be a preliminary step and we are aware of its limitations, some of which could be overcome at later research stages. Firstly, we mention that the limitations are mainly related to the fact that the empirical study is qualitative in nature and based on the analysis of a single case. Thus, the results cannot be generalized and the investigation carried out cannot be considered exhaustive. Since this is an ongoing research, it has not been possible in this first stage to assess the return in economic terms of CFR practices as Elica does not produce a social or sustainability report, neither does it operationalize benefits through specific indicators (key performance indicators of a qualitative as well as a quantitative nature are not stated).

We therefore conclude by proposing a research agenda in which the proposition shall be converted into testable hypothesis.

One line of inquiry could be that of the correlation between policies concerning workfamily balance and economic outcomes, with ethical and social goals. Another area of research could be the efficacy of such corporate policies in relation to the organizational culture that distinguishes the analyzed company. These possible lines of research can be developed with reference either to a single territorial context, or by adopting a comparative perspective in examining different regions or states characterized by different institutional contextual factors.

A further step would be to deepen the study of the process of CFR in the different subsidiaries of the Elica Group, by paying attention to the cultural differences and to the relation within organizational change and culture. Secondly, more attention should be placed to a comparative analysis taking into consideration other case-studies, both relative to large multinational companies and to small and medium-sized firm in different countries. 


\section{REFERENCES}

Ackerman, R.W. "How Companies respond to Social Demands". Harvard Business Review 51, no. 4 (1973): 88-98.

AIDP. L'Impresa Familiarmente Responsabile tra sostenibilità e competitività aziendale, 2010. Accessed February 5, 2012, www.aidp.it/aidp/2418.pdf4.

Allen, T.D. “Family-Supportive. Work Environment: the Role of Organizational Perceptions". Journal of Vocational Behavior, 58 (2001): 414-435.

Anderson, S.E., Coffey, B.S. and Byerly, R.T. "Formal Organizational Initiatives and Informal Workplace Practices: Links to Work-family Conflict and Job-Related Outcomes". Journal of Management 28, no. 6 (2002): 787-810.

Argandoña, A. "The Stakeholder Theory and the Common Good". Journal of Business Ethics 17, no. 9 (1998): 1093-1102.

Argandoña, A. “Fostering Values in Organizations". Journal of Business Ethics, 45 (2003): 15-29.

Argandoña, A. "Anthropological and Ethical Foundations of Organization Theory." In Rethinking Business Management. Examining the Foundations of Business Education edited by $\mathrm{S}$. Gregg and J.R. Jr. Stoner, 22-37. Princeton, NJ: The Witherspoon Institute, 2008.

Austin, J., Stevenson, H. and Wei-Skillern, J. "Social and Commercial Entrepreneurship: Some, Different or Both?". Entrepreneurship Theory and Practice 30, no.1 (2006): 1-22.

Barbour, R. Doing Focus Group. London: Sage, 2007.

Bebbington J., Higgins C. and Frame B. "Initiating Sustainable Development Reporting: Evidence from New Zealand". Accounting, Auditing \& Accountability Journal 22, no. 4 (2009): 588625.

Behson, S.J. "Which Dominates? The Relative Importance of Work-family Organizational Support and General Organizational Context on Employee Outcomes". Journal of Vocational Behavior 61(2002): 53-72.

Behson, S.J. "The Relative Contribution of Formal and Informal Organizational Work-Family Support". Journal of Vocational Behavior, 66(2005): 487-500.

Bevan, S., Dench, S., Tamkin, P. \& Cummings, J. Family-friendly Employment: The Business Case. Institute for Employment Studies, 1999.

Bond, S., Hyman, J. and Summers, J. Putting Family-friendly Working Policies into Practice. Joseph Rowntree Foundation, 2002.

Buckley, M.R., Beu, D.S., Frink, D.D., Howard, J.L., Berkson, H., Mobbs, T.A. and Ferris, G.R. "Ethical Issues in Human Resources Systems". Human Resource Management Review 11, no. 1 (2001): 11-29.

Butler, A., Gasser, M. and Smart, L. "A Social-cognitive Perspective on Using Family-friendly Benefits". Journal of Vocational Behavior, 65 (2004):57-70.

Calcagnini, G. and Favaretto, I. (eds). The Economics of Small Business. An International Perspective. London and New York: Springer Heidlbergh Dorrecht, 2011. 
Carrol, A.B. "A Three-dimensional Conceptual Model of Corporate Social Performance". Academy of Management Review 16, no. 4 (1979): 497-505.

CBSR. Best People Practices: The Integration of Values into People Practices. Vancouver, BC: CBSR, 2003.

CIPD - Chartered Institute of Personnel and Development. Corporate Social Responsibility and HR's Role. London, UK: CIPD, 2002.

Chrisman, J.J., Chua, J.H. and Zahra, S.A. "Creating Wealth in Family Firms through Managing Resources: Comments and Extensions". Entrepreneurship, Theory and Practice, Summer, (2003): 359-365.

Clarke, M.M. "New Sentencing Guidelines to Reward Ethical Culture, Compliance, Commitment". HR Magazine, September 28, 2004.

Collier, J. and Esteban, R., "Corporate Social Responsibility and Employee Commitment". Business Ethics: A European Review 16, no. 1 (2007): 19-33.

CRF. Top Employers Italia 2012. Milano: F. Angeli, 2012.

Corbetta, P. La ricerca sociale: metodologie e tecniche. Le tecniche qualitative. Bologna: II Mulino, 2003.

Del Baldo, M., "Corporate Social Responsibility and Corporate governance in Italian SMEs: Toward a "Territorial" Model Based on Small "Champions of CSR". International Journal of Sustainable Society 2, no. 3 (2010): 215-247.

Del Baldo M. "Corporate Social Responsibility and Corporate Governance in Italian Smes: the Experience of some "Spirited Businesses". Journal of Management and Governance 16, no. 1 (2012):1-36.

Deniz, D. and Cabrera, M.K., "Corporate Social Responsibility and Family Business in Spain". Journal of Business Ethics 56, no. 19 (2005): 59-71.

Desrochers, S., Lehoux, M., Halpern, D. and Tse, A. Implicit Measures of Work-Family Linkages? Findings of a Validation Study on Working Students at a Local Community College. Berger Institute for Work, Families and Children, 2004.

Desrochers, S., Lehoux, M., Halpern, D., and Riggio, H. Work Family Blurring in Two Local Organization: Findings of Studies Conducted in February and March of 2004. Berger Institute for Work, Families and Children, 2004.

Dex, S., Smith, C. and Winter, S. Effects of Family-friendly Policies on Business Performance. Judge Institute of Management Studies, 2001.

Downey, S. "The Relationship Between Corporate Culture and Corporate Identity". Public Relations Quarterly 31. No. 4 (1986): 7-13.

Dyer, W. G., Jr. Cultural Change in Family Firms: Anticipating and Managing Business and Family Transitions. San Francisco: Jossey-Bass, 1986.

EC. A renewed EU strategy 2011-14 for Corporate Social Responsibility. 25.10.2011 COM(2011) 681 final. Brussels, 2011. 
Eisenhardt, K.M. "Building Theories from Case Study Research". Academy of Management Review 14, no. 4 (1989): 532-550.

Eisenhardt, K.M. and Graebner, M.E. "Theory Building from Cases: Opportunities and Challenges". Academy of Management Journal 50, no. 1 (2007): 25-32.

Elkington, J. The Green Capitalism. London: Victor Gollancz, 1987.

Elkington, J. "Towards the Sustainable Corporation: Win-win business strategies for Sustainable Development". California Management Review 36, no. 2 (1994): 90-100.

EU. Corporate Social Responsibility: A business contribution to Sustainable Development, Com(2002)347 final. Brussels, 2002.

EU. Implementing the Partnership for Growth and Jobs: Making Europe a Pole for Excellence on Corporate Social Responsibility. Com(2006)136, final. Brussels, 2006.

EU. European alliance for families, Promoting Family-Friendliness at Workplace through Awards, Audits and Labeling Schemes, 2010, accessed June 21, 2011,http://ec.europa.eu/employment_social/emplweb/families/admintool/userfiles/file/Bosnicovareport-formatted.pdf.

EURISKO Corporate Social. Responsibility Monitor 2009, accessed July 2, 2012, http:// www.sodalitas.it/files/18/Anselmi_Eurisko.pdf

Fagan, C. Working-Time Preferences and Work-Life Balance in the EU: Some Policy Considerations for Enhancing the Quality of Life. European Foundation for the Improvement of Living and Working Conditions, 2003.

Faldetta, G. Corporate Family Responsibility e Work-life Balance. Milano: F.Angeli, 2008.

Flik, U. An Introduction to Qualitative Research (4 ${ }^{\text {th }}$ ed.). London: Sage, 2009.

Fondazione M. Vigorelli (2012), Osservatorio CFR, rapporto biennale 2011-2012 dell'osservatorio nazionale sulla famiglia, 17 maggio 2012, accessed October 20, 2012, http:// www.marcovigorelli.com/index.php/osservatoriocfr.html

Freeman, R.E. and Evan, W. "Corporate Governance: a Stakeholder Interpretation". Journal of Behavioral Economics 19, no. 4 (1990): 337-59.

Freeman, R.E., Harrison, J., Wicks, A., Palmar, B.L. and De Colle, S. Stakeholder Theory. The State of the Art. Cambridge, N.Y: Cambridge University Press, 2010.

Fuà, G. and Zacchia, C. (eds). Industrializzazione senza fratture. Bologna: Il Mulino, 1983.

Gallo, M.A. "The Family Business and its Social Responsibilities". Family Business Review 17, no. 2 (2004): 135-149.

Garriga, E. and Melé, D. “Corporate Social Responsibility Theories: Mapping the Territory". Journal of Business Ethics 53, no. 1 (2004): 51-71.

Gartner, W.B. "Entrepreneurial Narrative and a Science of the Imagination". Journal of Business Venturing, 22 (2007): 613-627.

Glass, J.L. and Finley, A. "Coverage and Effectiveness of Family-Responsive Work-place Policies". Human Resource Management Review, 12 (2002): 313-337. 
Greenblatt, H. "Work/Life Balance: Wisdom or Whining". Organizational Dynamic 31, no. 2 (2002): 177-193.

Gray, H. Family-Friendly Working, What a Performance: An Analysis of the Relationship Between the Availability of Family-Friendly Policies and Establishment Performance. London: Centre for Economic Performance - London School Of Economics and Political Science, 2001.

Gray, R., Owen, D. and Adams, C. Accounting and Accountability: Changes and Challenges in Corporate Social and Environmental Reporting. London: Prentice-Hall, 1996.

Grant, T. Corporate Social Responsibility: A Necessity Not a Choice. Bangkok, 2008.

Greenhaus, J.H., Collins, K.M. and Shaw, J.D. "The Relation between Work-family Balance and Quality Life". Journal of Vocational Behavior, 63 (2003): 510-531.

Hancock, K. "Employee Engagement Partnerships: can they Contribute to the Development of an Integrated CSR Culture'?" In CPI (Cambridge Programme for Industry) 2005. Partnership Matters: Current Issues in Cross-sector Collaboration, no 3 (2005): 7-20. Retrieved at www. cpi.cam.ac.uk/pccp/ ParternMatters3.pdf. Accessed May 30, 2012.

Hofstede, G. Culture's Consequences. International Differences in Work-related Values. London: Sage, 1980.

Hochschild, A.R. "The Time Bind: When Work Becomes Home and Home Becomes Work". California Management Review 39, no. 4 (1997): 79-97.

IESE (2008), La tua azienda è Family-friendly? accessed June 3, 2012, http:// www3.iese.edu/ifrei/ ifrei_italia/h0.asp.

ISFOL Rapporto 2009, accessed September 2, 2011, http;// www.isfol.it/DocEditor/test/File/Rapporto\%20lsfol\%202009/Sintesi_2009.pdf

IFERA, “Family Firms Dominate”. Family Business Review 16, no. 4 (2003): 235-239.

Jones, T.M. "Corporate Social Responsibility Revisited, Redifined". California Management Review 22, no. 2 (1980): 59-67.

Kapitàny, B., Kovacs, K. \& Krieger, H. Working and Living in an Enlarged Europe. European Foundation for the improvement of Living and Working Conditions, 2005.

Kodz, J, Harper, H. and Dench, S. Work-Life Balance. Beyond the Rhetoric. Institute for Employment Studies, Report 384, 2002.

Koos, S. "The Institutional Embeddedness of Social Responsibility: A Multilevel Analysis of Smaller Firms' Civic Engagement in Western Europe". Socioeconomic Review 10, no. 1 (2012): 135162.

Lombardy Region. Lombardy 2020, From the Green Paper to the White Paper - Roadmap for the reconciliation of Family and Work-life. Action Plan towards a regional system in support of reconciliation objectives 2011 - 2013, 13 October 2011:1-17, accessed March, 2, 2012, http:// www.premiofamiglialavoro.regione.lombardia.it/cs/2011.

McElroy, J.C. "Managing Workplace Commitment by Putting People First". Human Resource Management Review 11, no. 3 (2001): 327-336. 
Mees, A. and Bonham, J. "Corporate Social Responsibility Belongs with HR". Canadian HR Reporter, April 5 (2004): 11-13.

Melcrum. Engaging Employees in Corporate Responsibility: How the World's Leading Companies Embed CR in Employee Decision-making. London, UK, 2006.

Melé, D. Not Only Stakeholder Interests. The Firm Oriented Toward the Common Good. Notre Dame: Notre Dame University Press, 2002.

Melé, D. Business Ethics in Action. Seeking Human Excellence in Organizations. Hampshire, GB: Palgrave Macmillan, 2009.

Melé, D. "The Firm as a "Community of Persons": a Pillar of Humanistic Business Ethos". Journal of Business Ethics 106, no. 1 (2012): 89-101.

Merton, R.K. "The Focused Interviews and Focus Groups: Continuities and Discontinuities". Public Opinion Quarterly, 51 (1987): 550-556.

Morgan, D.L. Focus Groups as Qualitative Research. Newbury Park, CA: Sage, 1988.

Morgan, G., Ryu, K., and Mirvis, P. "Leading Corporate Citizenship: Governance, Structure and Systems". Corporate Governance, 9 (2009): 39-49.

Naumes, W. and Naumes, M.J. The Art and Craft of Case Writing, $2^{\text {nd }}$ ed. London: ME Sharpe, 2006.

OECD "Bosses and Babies: Reconciling Work and Family Life", Vol. 1, Australia, Denmark and the Netherlands; Vol. 2, Austria, Ireland and Japan; Vol. 3, New Zealand, Portugal and Switzerland; Vol. 4, Canada, Finland, Sweden and United Kingdom. OECD, 2002, 2005.

Patton, M.Q. Qualitative Evaluation and Research Method ( $3^{\text {rd }}$ ed.). London: Sage, 2002.

Ponzellini, A.M. and Tempia, A. Quando il lavoro è amico. Aziende e famiglia: un incontro possibile. Roma: Edizioni Lavoro, 2003.

Puchta, C. and Potter, J. Focus Group Practice. London: Sage, 2004.

Putnam, R.D. Making Democracy Work. Civic Tradition in Modern Italy. Princeton, NJ: Princeton University Press, 1993.

Reynolds, J. "When too Much is not Enough: Actual and Preferred Hours in the United States and Abroad". Sociological Forum 19, no. 1 (2004): 89-120.

Rode, J.C., Rehg, M.T., Near, J.P. and Underhill, J.R. "The Effect of Work/Family Confilct on Intention to Quit: The Mediating Roles of Job and Life Satisfaction". Applied Research in Quality of Life, 2 (2002): 65-82.

Roehling, P.V., Roehling, M.V. and Moen, P. "The Relationship Between Work-Life Policies and Practices and Employee Loyalty: A Life Course Perspective". Journal of Family and Economic Issues 22, no. 2 (2001): 141-170.

Schein, E. H. "The Role of the Founder in Creating Organizational Culture". Organizational Dynamics, Summer (1983): 13-28.

Sorci C. (ed). Lo sviluppo integrale delle aziende. Milano: Giuffrè, 2007. 
Spence, L.J. "Towards a Human Centred Organisation: The Case of the Small Firms", paper presented at the 3rd Conference on Ethics in Contemporary Human Resource Management, Imperial College, London, 7 January, 2000.

Spence, L.J., Habisch, A. and Schmidpeter, R. (ed.). Responsibility and Social Capital: The World of Small and Medium Sized Enterprises. Palgrave: MacMillan, 2004.

Strandberg, C. "The Role of Human Resource Management in Corporate Social Responsibility. Issue Brief and Roadmap, Report", Strandberg Consulting, May 2009, Burnaby, BC: 1-36, accessed July, 3, 2012, http:// www.corostrandberg.com.

Tencati, A. and Zsolnai, L. "The Collaborative Enterprise". Journal of Business Ethics 17, no. 3 (2008): 311-325.

Todd, S. Improving Work-Life Balance - What are Other Countries Doing? Canada: Labour Program, Human Resources and Skills Development, 2004.

Treviño, L.K., Butterfield, K.D. and McCabe, D. "The Ethical Context in Organizations: Influences on Employee Attitudes and Behaviours". Business Ethics Quarterly 8, no. 3 (1998): 447-476.

Treviño, L.K. and Brown, M.E. "Managing to be Ethical: Debunking Five Business Ethics Myths". Academy of Management Executive 18. No. 2 (2004): 69-81.

Uhlaner, L.M., van Goor-Balk, H.F.M. and Masurel, E. "Family Business and Corporate Social Responsibility in a Sample of Dutch Firms". Journal of Small Business and Enterprise Development 11, no. 2 (2004): 186-194.

Unioncamere. Models of Corporate Social Responsibility in Italy. Executive Summary. Rome: Italian Union of Chambers of Commerce, Industry, Craft and Agriculture, 2003.

Unioncamere. "Le attività del Sistema Camerale sulla Responsabilità sociale", febbraio 2007, accessed May, 4, 2011, http:// www.csr.unioncamere.it.

Unioncamere. Le Piccole e Medie imprese nell'economia italiana. Rapporto 2009, Istituto Tagliacarne. Milano: F. Angeli, 2010.

Vergara, C. "Programmazione, controllo e sviluppo integrale delle aziende". In Lo sviluppo integrale delle aziende edited by C. Sorci, 41-66. Milano: Giuffrè, 2007.

Waddock, S. "Parallel Universes: Companies, Academics and the Progress of Corporate Citizenship". Business and Society Review 109, no. 1 (2004): 5-42.

Waismel-Manor, R., Moen P. and Sweet, S. What Factors Predict Dual-Earner Middle-Class Couples Feeling Highly Successful in Their Jobs, Families, and Balancing Both? Cornell Employment and Family Careers Institute, 2002.

Whitener, E.M. "Do "high-commitment" Human Resource Practices affect Employee Commitment? A cross-level Analysis using Hierarchical Linear Modeling". Journal of Management 27, no. 5 (2011): 515-535.

Weaver, G. "Ethics and Employees: Making the Connection". Academy of Management Executive 18, no. 2(2004): 121-125. 
Weaver, G., Treviño, L.K. and Cochran, P.L. "Integrated and Decoupled Corporate Social Performance: Management Commitments, External Pressures and Corporate Ethics Practices". Academy of Management Journal 42, no. 5 (1999): 539-552.

Werbel, J. and Walter, M.H. "Changing Views of Work and Family Roles. A Symbiotic Perspective". Human Resource Management Review, 12(2002): 293-298.

Wood, A. "Blending Business and Benevolence". Chemical Week 158, no. 5 (1996): $42-4$.

Yeandle, S., Crompton, R., Wigfield and A. Dennett, J. Employers, Communities and FamilyFriendly Employment Policies. Joseph Rowntree Foundation, 2002.

Yin, R.K. Applications of Case Study Research, $2^{\text {nd }}$ ed. Thousand Oaks: Sage, 2003.

Young, S. and Marais, M. "A Multi-level Perspective of CSR Reporting: The Implications of National Institutions and Industry Risk Characteristics". Corporate Governance: An International Review 20, no. 5 (2012): 432-450.

Zadek, S., Pruzan, P. and Evans, R. (eds.). Building Corporate Accountability: Emerging Practices in Social and Ethical Accounting and Auditing. London: Earthscan Publication, 1997.

Zamagni, S. (ed.). The Economics of Altruism. Hants: E. Elgar, 1995.

Zamagni, S. L'economia del bene comune. Roma: Città Nuova, 2007.

Zedeck, S. and Mosier, K.L. "Work in the Family and Employing Organization". American Psychologist 45, no. 2 (2003): 240-251. 